\title{
Reliability Analysis of Metro Door System Based on FMECA
}

\author{
Xiaoqing Cheng ${ }^{1}$, Zongyi Xing ${ }^{2}$, Yong Qin ${ }^{1}$, Yuan Zhang ${ }^{1}$, Shaohuang Pang ${ }^{3}$, Jun Xia ${ }^{4}$ \\ ${ }^{1}$ State Key Laboratory of Rail Traffic Control and Safety, Beijing Jiaotong University, Beijing, China; ${ }^{2}$ School of Automation, Nan- \\ jing University of Science and Technology, Nanjing, China; ${ }^{3}$ Guangzhou Metro Corporation, Guangzhou, China; ${ }^{4}$ School of Me- \\ chanical Engineering, Nanjing University of Science and Technology, Nanjing, China. \\ Email: zhangyuan_111@126.com
}

Received May 23 ${ }^{\text {rd }}, 2013$; revised September $8^{\text {th }}, 2013$; accepted October $4^{\text {th }}, 2013$

Copyright (c) 2013 Xiaoqing Cheng et al. This is an open access article distributed under the Creative Commons Attribution License, which permits unrestricted use, distribution, and reproduction in any medium, provided the original work is properly cited.

\begin{abstract}
The metro door system is one of the high failure rate subsystems of metro trains. The Failure Mode, Effects and Criticality Analysis (FMECA) method is applied to analyze the reliability of metro door system in this paper. Firstly, failure components of the door are statistically analyzed, and the major failure components are determined. Secondly, failures are classified according to their impacts on operation, and methods of calculating failure mode criticality and the related coefficients are illustrated. Finally, the FMECA is detailed in the selected 12 failure modes, and the failure modes are discovered that they have the most significant effect on metro door system. The obtained results can be used for optimal design and maintenance of the metro door system.
\end{abstract}

Keywords: Reliability; Sliding Plug Door; FMECA; Criticality

\section{Introduction}

Metro door system is one of the subsystems which has a high failure rate in metro vehicles. Frequent failures of the door bring much inconvenience to passengers and have a negative impact on metro train corporation. Currently, reliability research has become an important part in developing, using, maintaining and evaluating a modern product. So, to determine the key components and failure modes, making a reliability analysis on metro door system has an important significance, and it's very useful for maintenance and optimal design of door system.

Failure Mode Effects and Criticality Analysis (FMECA) is a common reliability analysis method for products, which has been applied to product designs and maintenance decisions in many fields. ZHANG Qiang, et al. [1] applied FMECA method to make a reliability analysis on truck bogie, the criticality of the failure modes on bogie was identified and the result could provide a useful reference to bogie maintenance decision-making and daily management. GENG Feng et al. [2] used FMECA method to analyze the criticality of failure modes in highspeed EMU brake system for classifying severity of fail- ure modes and making appropriate suggestions for improvements. GU Wen-juan et al. [3] utilized the traditional FMECA and fault tree analysis (FTA) methods to conduct a comprehensive analysis on train security.

The FMECA method is applied to the door system of metro train in this paper. According to the door fault information which is found in the main line operation and maintenance of metro train corporation, the FMECA analysis is carried out on the several key components which have a high failure rate, so the failure modes which have a great effect on door system are obtained and auxiliary decision-making reference could be provided for maintenance of door system.

\section{The Brief Introduction of FMECA}

The FMECA method is mainly used to analyze all possible failure modes of every component belong to one system and their impacts on the system, and all failure modes are classified and assessed comprehensively according to their failure level and probability of occurrence or criticality [4]. The FMECA method could found the key components and the key failure modes, and provide the foundation for maintenance and improvement of the product. 
The FMECA method includes two parts: Failure Mode Effects Analysis (FMEA) and Criticality Analysis (CA). FMECA is developed and perfected gradually on the basis of FMEA. In 1950s, FMEA was applied to operating system design analysis of fighter plane in USA, and some good results were achieved. From the late 1960s to the early 1970s, the FMECA method had been widely used in many fields, such as aviation, aerospace, weapons, cars and so on. In the early 1980s, the concept and method of FMECA began to become popular at domestic, and the GB/T 7826-1987 <System reliability analysis technique failure mode and effects analysis (FMECA)> and a series of other standards were promulgated. Currently, the FMECA method have received a great degree of popularity in aviation, aerospace, weapons, ships, electronics, automotive and other industrial fields, and played an important role in ensuring the reliability of products [5].

\section{Door Structure and Statistical Analysis of Failure Location}

\subsection{Description of Metro Door Structure}

Door system mainly consists of five subsystems: bearing orientation mechanism, basic components, electric control device, internal and external operating mechanism, driving and braking unit [6]. The chassis, the rack, long and short guide pins, rails and bearings mainly constitute bearing orientation mechanism; basic components include door leaves, adhesive tapes, indicator lights and locating pin, etc.; electric control device mainly consists of an EDCU, switches, buttons and so on; the unlocking device and a handle, etc. comprises internal and external operating mechanism; driving and braking unit is comprised of an electric motor, screw-nut pair, end unlocking and two belt wheels and so on. The basic components of five subsystems are shown in Table 1.

\subsection{Statistical Analysis of Fault Location}

The reliability analysis of door system in this paper is carried out on the basis of the 18-month fault information which is obtained from the main line operation and maintenance of a metro train corporation. And the fault information of door system contains all fault records of 28 vehicles. A statistical analysis is conducted on the collected fault information, and the results are shown in Table 2.

This shows that total 443 cases of failure occurred, the 297 cases of which belong to the four components including the door controller EDCU, door closing limit switch S1, nut component and portable mast mounting rank top 4 , which occupy $67 \%$ of the total failures. So the four components could be considered as major fault factors and should be analyzed in detail. In addition, the
Table 1. Basic structure of door system.

\begin{tabular}{cc}
\hline Door subsystem & The basic component parts \\
\hline $\begin{array}{c}\text { Bearing } \\
\text { orientation } \\
\text { mechanism }\end{array}$ & $\begin{array}{c}\text { Rack, portable mast mounting, long and short } \\
\text { guide pins, up and down rails, pressure roller, } \\
\text { linear bearing and so on }\end{array}$ \\
$\begin{array}{c}\text { Basic } \\
\text { components }\end{array}$ & $\begin{array}{c}\text { Adhesive tapes, glass, buzzer, abaculus, buffer } \\
\text { head, locating pin, indicator lights, ground wire, } \\
\text { door leaves and so on }\end{array}$ \\
$\begin{array}{c}\text { Electric } \\
\text { control device }\end{array}$ & $\begin{array}{c}\text { EDCU, door closing limit switch, chopping } \\
\text { locking limit switch, door control button and so on }\end{array}$ \\
$\begin{array}{c}\text { Internal } \\
\text { and external } \\
\text { operating } \\
\text { mechanism }\end{array}$ & $\begin{array}{c}\text { Internal emergency unlocking device, steel } \\
\text { wire rope, external emergency device, internal } \\
\text { operating handle and so on }\end{array}$ \\
$\begin{array}{c}\text { Driving and } \\
\text { braking unit }\end{array}$ & $\begin{array}{c}\text { Electric motor, belt wheel, toothed belt, } \\
\text { screw-nut pair, end unlocking device, shifting } \\
\text { fork, middle unlocking component and so on }\end{array}$ \\
\hline
\end{tabular}

Table 2. Statistics of door failure components.

\begin{tabular}{cc}
\hline Door component & Failure numbers \\
\hline EDCU & 138 \\
Limit switch S1 & 61 \\
Nut component & 50 \\
Portable mast mounting & 48 \\
Pressure roller & 25 \\
Screw & 22 \\
middle unlocking component & 19 \\
Limit switch S4 & 18 \\
Limit switch S3 & 17 \\
Long guide pin & 15 \\
Idler wheel & 11 \\
Door indicator light & 10 \\
End unlocking mechanism & 9 \\
\hline
\end{tabular}

failure numbers of pressure roller, drive screw, door locking limit switch S4, emergency unlocking limit switch S3, middle unlocking component, long guide pin, idler roller, door indicator light and end unlocking device are a little low, but they still occupy approximately onethird of the total failures number, so the maintenance department should pay enough attention to them.

\section{FMECA on Door System}

\subsection{Door System Failure Classification}

Failure level stands for the severity of the consequences of failure mode on system. The failure level should be determined firstly, and then the criticality of every failure mode can be ultimately determined by using the criticality matrix diagram. In this paper, the failure level of every failure mode is divided into five categories according to the actual situation [7], as shown in Table 3. 
Table 3. Failure level classification.

\begin{tabular}{|c|c|}
\hline Failure level & Definition \\
\hline I & $\begin{array}{l}\text { Passenger safety is harmed due to door failure during } \\
\text { train operation process; }\end{array}$ \\
\hline II & $\begin{array}{l}\text { Door failures can't be ruled out, so the train can't } \\
\text { continue to operate and the passengers have to get off; }\end{array}$ \\
\hline III & $\begin{array}{l}\text { Door failures can't be resolved in short time, the door } \\
\text { must be removed, or the train won't continue to operate; }\end{array}$ \\
\hline IV & $\begin{array}{l}\text { The driver could settle the failure, but the failures } \\
\text { cause a little delay to main line operating; }\end{array}$ \\
\hline V & $\begin{array}{l}\text { Door failures have no impact on train operations and } \\
\text { could be maintained after returning the train depot }\end{array}$ \\
\hline
\end{tabular}

\subsection{Calculation Method of Failure Mode Criticality}

The component failure mode criticality $C_{i}$ is used to evaluate the perniciousness of a single failure mode, and it could be calculated as follows:

$$
C_{i}=\lambda \alpha \beta t
$$

where, $\lambda$ is the failure rate of a component; $\alpha$ is the frequency ratio of the failure mode, which means the percentage ratio of a failure mode to a component's total failure modes; $\beta$ stands for the effect probability of a failure mode; $t$ is the working time of a component.

Component criticality $C_{c}$ is used to evaluate the perniciousness of every component and it could be calculated as follows:

$$
C_{c}=\sum_{i=1}^{n} C_{i}
$$

where, $n$ is the number of failure modes for every component.

The failure rate of every component could be obtained by using the average failure rate calculation method [8], which is calculated as:

$$
\lambda=N / t
$$

where, $\lambda$ is the failure rate of a component; $N$ is the failure numbers within the specified time for a component, $t$ is the working time of a component.

Failure effect probability $\beta$ is the identified failure effect that a failure mode leads to in the conditional probability, $\beta$ is usually an estimated value. During FMECA on metro door system, $\beta$ is as follows [9]: $\beta=1.0$, which means that the system is certainly malfunction; $\beta=0.5$, which means that the system may malfunction; $\beta=0.1$, which means that the system rarely fails; $\beta=0$, which means that the failure mode have no effect on the system.

\subsection{Ascertain the Criticality of Door Failure Mode}

During reliability analysis of door system, the FMECA method is conducted on EDCU, door closing limit switch, nut component, and portable mast mounting four components which have been deemed to have a high failure rate, as shown in Table 4. Obviously, four components only cause failure level of III, IV, V, no I and II. Failure modes of EDCU belong to failure level of III and IV, and closing limit switch S1 or nut component only cause failure level of III, and failure modes of portable mast mounting have the failure level of IV and V. When the failure level is III, the maximum and minimum criticality component is EDCU and nut component, the criticality is 125.67 and 25.53 respectively; when the failure level is $\mathrm{IV}$, the maximum and minimum criticality component is EDCU and portable mast mounting, the criticality is 6.21 and 2.16 respectively; when the failure level is $\mathrm{V}$, only failure modes of portable mast mounting have the failure level, the criticality is 21.8 .

According to failure level and failure mode criticality in Table 4, combining with statistical analysis of failure data, the criticality matrix diagram could be obtained, as shown in Figure 1.

The Figure 1 shows the relationship between the failure levels and criticality of 12 failure modes, which is the further of failure mode distribution points along the diagonal direction from the origin, the greater of the failure mode criticality, and indicates that more attention should be paid to corresponding defective parts [10].

From the Figure 1, we can conclude apparently that the failure modes in descending order of criticality are that 2 (EDCU function failure), 3 (S1 breakage), 6 (Nut component breakage), 5 (S1 function failure), 9 (Nut component loose), 4 (S1 abnormal clearance), 7 (Nut component poor lubrication) and 8 (Nut component angle offset), 1 (EDCU plug loose), 12 (Portable mast mounting bolts loose), 11 (Portable mast mounting has crackson screws), and 10 (Portable mast mounting bushing for

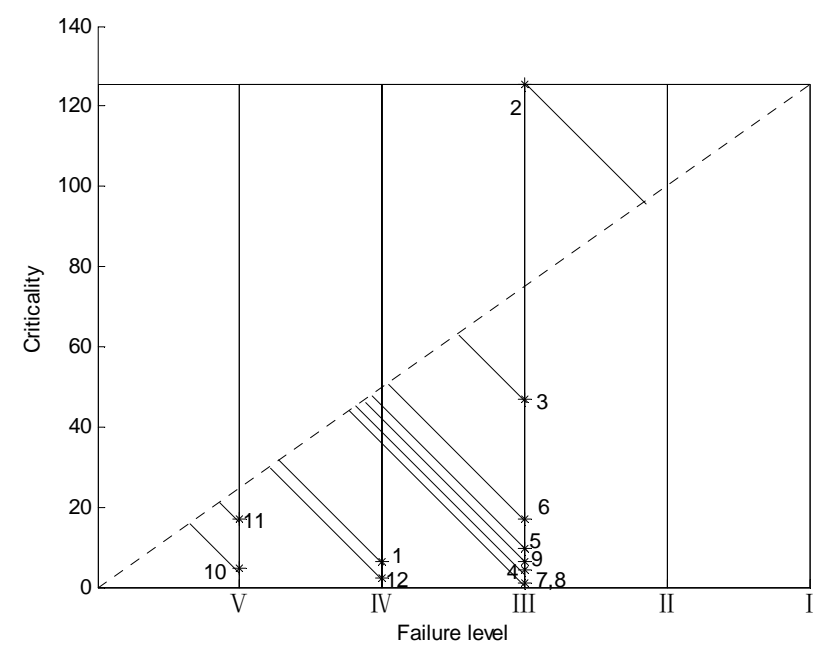

Figure 1. Criticality matrix diagram of failure modes. 
Table 4. FMECA of metro door system.

\begin{tabular}{|c|c|c|c|c|c|c|c|c|c|c|}
\hline No. & Component & $\begin{array}{l}\text { Failure } \\
\text { mode }\end{array}$ & Failure cause & Failure effect & $\begin{array}{l}\text { Failure } \\
\text { level }\end{array}$ & $\lambda$ & $\alpha$ & $\beta$ & $C_{i}$ & $C_{c}$ \\
\hline 1 & \multirow{2}{*}{ EDCU } & $\begin{array}{l}\text { Plug } \\
\text { loose }\end{array}$ & $\begin{array}{l}\text { Not inserted in place; } \\
\text { Vehicle vibrations }\end{array}$ & $\begin{array}{l}\text { Door can't operate } \\
\text { normally }\end{array}$ & IV & \multirow{2}{*}{5.19} & 0.09 & 0.5 & 6.21 & $\begin{array}{c}\text { III: } \\
125.67\end{array}$ \\
\hline 2 & & Function failure & $\begin{array}{l}\text { Safety relays/communication } \\
\text { interfaces are damaged }\end{array}$ & $\begin{array}{l}\text { Door can't operate } \\
\text { normally }\end{array}$ & III & & 0.91 & 1 & 125.67 & \multirow[t]{2}{*}{$\begin{array}{l}\text { IV: } \\
6.21\end{array}$} \\
\hline 3 & & Breakage & $\begin{array}{l}\text { Retainer lose; Thrust pressure } \\
\text { ring lose; Arm spring failure }\end{array}$ & $\begin{array}{l}\text { The train } \\
\text { won't start }\end{array}$ & III & \multirow{3}{*}{2.29} & 0.77 & 1 & 46.92 & \\
\hline 4 & $\begin{array}{l}\text { Door } \\
\text { closing limit } \\
\text { switch S1 }\end{array}$ & $\begin{array}{l}\text { Abnormal } \\
\text { clearance }\end{array}$ & $\begin{array}{l}\text { No adjustment } \\
\text { in place }\end{array}$ & $\begin{array}{l}\text { Start the pinch } \\
\text { function; The train } \\
\text { won't start }\end{array}$ & III & & 0.07 & 1 & 4.27 & \multirow[t]{2}{*}{$\begin{array}{l}\text { III: } \\
60.94\end{array}$} \\
\hline 5 & & $\begin{array}{l}\text { Function } \\
\text { failure }\end{array}$ & $\begin{array}{l}\text { Quality defects; } \\
\text { End of life }\end{array}$ & $\begin{array}{l}\text { Indicator light } \\
\text { anomalies; The train } \\
\text { won't start }\end{array}$ & III & & 0.16 & 1 & 9.75 & \\
\hline 6 & \multirow{4}{*}{$\begin{array}{c}\text { Nut } \\
\text { component }\end{array}$} & Breakage & $\begin{array}{l}\text { Screw bolts missing; } \\
\text { Shifter level fracture }\end{array}$ & $\begin{array}{l}\text { Door can’t operate; } \\
\text { Unable to lock and } \\
\text { unlock the door }\end{array}$ & III & \multirow{4}{*}{1.88} & 0.68 & 0.5 & 17.01 & \multirow{4}{*}{$\begin{array}{l}\text { III: } \\
25.53\end{array}$} \\
\hline 7 & & Poor lubrication & $\begin{array}{l}\text { Lacking of maintenance; } \\
\text { Lubricant quality bad }\end{array}$ & $\begin{array}{l}\text { Door operates slowly; } \\
\text { Abnormal sound }\end{array}$ & III & & 0.04 & 0.5 & 1.01 & \\
\hline 8 & & $\begin{array}{l}\text { Angle } \\
\text { offset }\end{array}$ & No adjustment in place & $\begin{array}{l}\text { Start the pinch, the } \\
\text { door can't operate }\end{array}$ & III & & 0.02 & 1 & 1.01 & \\
\hline 9 & & Loose & $\begin{array}{l}\text { Locking washers } \\
\text { not into the slot }\end{array}$ & $\begin{array}{l}\text { Start the pinch, the } \\
\text { door can't operate }\end{array}$ & III & & 0.26 & 0.5 & 6.5 & \\
\hline 10 & & $\begin{array}{l}\text { Bushing } \\
\text { for } \\
\text { cracks }\end{array}$ & $\begin{array}{l}\text { Material defects; } \\
\text { Improper heat treatment }\end{array}$ & $\begin{array}{l}\text { The door can’t be } \\
\text { closed tightly }\end{array}$ & V & & 0.2 & 0.5 & 4.79 & \multirow{3}{*}{$\begin{array}{l}\text { IV: } \\
2.16 \\
\text { V: } \\
21.8\end{array}$} \\
\hline 11 & $\begin{array}{l}\text { Portable } \\
\text { mast } \\
\text { mounting }\end{array}$ & $\begin{array}{l}\text { Screw } \\
\text { has } \\
\text { cracks }\end{array}$ & Too much stress & $\begin{array}{l}\text { There is the risk that } \\
\text { the door can't operate }\end{array}$ & $\mathrm{V}$ & 1.8 & 0.71 & 0.5 & 17.01 & \\
\hline 12 & & $\begin{array}{l}\text { Mounting } \\
\text { bolts } \\
\text { loose }\end{array}$ & $\begin{array}{l}\text { No adjustment in place; } \\
\text { Vehicle vibrations }\end{array}$ & $\begin{array}{l}\text { The door can’t be } \\
\text { closed tightly }\end{array}$ & IV & & 0.09 & 0.5 & 2.16 & \\
\hline
\end{tabular}

${ }^{*}: \lambda$ is the failure rate, $\alpha$ is the failure mode frequency ratio, $\beta$ is the effect probability, $C_{i}$ is the failure mode criticality, $C_{c}$ is the component criticality.

cracks). It is thus clear that the criticality of EDCU function failure and door closing limit switch S1 breakage are greater than other failure modes criticality, and they should be regarded as the key failure modes of the door system and the focus of attention in the routine maintenance. In addition, corresponding improvement measures which are combined with the actual situation should be given to door closing limit switch S1 breakage and other failure modes.

\section{Conclusion}

Through statistical analysis of defective components of metro door system, the FMECA method is utilized to analyze four components which have a high failure rate. The results show that the EDCU function failure and the breakage of limit switch S1 are the weakness of door system, and should be concerned in the maintenance operation. By site investigation, the results are consistent with the actual experience of field engineers. So the effectiveness of the method is verified, and the results will provide the technical support for the metro door design and maintenance decision-making.

\section{Acknowledgements}

The authors would like to express their thanks to the editor and anonymous reviewers for their help in revising the manuscript. This research is sponsored by National Key Technology R\&D Program of China (2011 BAG01B05) and National High-Tech R\&D Program of China (863 Program No. 2011AA110501).

\section{REFERENCES}

[1] Q. Zhang, Y.-Z. Song, X.-L. Guo, et al., "Failure Mode Analysis of Bogie Frame Based on FMECA,” Railway Locomotive Vehicle, Vol. 27, No. 3, 2007, pp. 35-37.

[2] F. Geng, M.-Z. Chang and J. Mao, "RAMS Study on High Speed EMU Brake System Based on FMECA," Railway Vehicle, Vol. 50, No. 5, 2012, pp. 31-33.

[3] W.-J. Gu and S.-S. Xue, "Functional FMECA and FTA 
Analyzing the Safety of the Train Synthetically," Study on the City Rail Transit, No. 6, 2012, pp. 84-87.

[4] C. B. Ma, Z. Gao and L. Yang, "Safety Analysis of Airborne Weather Radar Based on Failure Mode, Effects and Criticality Analysis,” Procedia Engineering, Vol. 17, 2011, pp. 407-414.

http://dx.doi.org/10.1016/j.proeng.2011.10.048

[5] A.-M. Liu, "Research and Application of the Rail Vehicle Door System Reliability," Nanjing University of Science and Technology, Nanjing, 2008.

[6] S.-Y. Zhu and J.-S. Lv, "Vehicle Maintenance Worker," China Labor and Social Security Publishing Express, Beijing, 2011.

[7] Z.-H. Shen, "Fault Diagnosis System of Vehicles for
Guangzhou Metro,” Electric Drive for Locomotive, No. 4, 2000, pp. 26-31.

[8] M. Scorsetti, C. Signori and P. Lattuada, “Applying Failure Mode Effects and Criticality Analysis in Radio Therapy: Lessons Learned and Perspectives of Enhancement," Radiotherapy and Oncology, Vol. 94, No. 3, 2010, pp. 367-374. http://dx.doi.org/10.1016/j.radonc.2009.12.040

[9] G.-X. Shen, H.-Y. Li, Y.-Z. Zhang, et al., "Failure Mode Analysis on the CNC Lathe Turret System," Machine Tool \& Hydraulics, Vol. 39, No. 19, 2011, pp. 126-129.

[10] Y. F. Meng, J. Y. Cai and G. F. Wang, "Fault Analysis of Radar System on FMECA,” Journal of Ordnance Engineering College, Vol. 12, 2000, pp. 20-23. 